\title{
DESTINATION BRANDING MODEL OF AN ECOLOGICAL TOURISM VILLAGE IN BALI, INDONESIA
}

\author{
I Ketut MASTIKA* \\ University of Jember, Faculty of Social and Political Science, Department of Business Administration, \\ Jalan Kalimantan 57 Jember, East Java, Indonesia, e-mail: i.ketut.mastika@unej.ac.id \\ Umar NIMRAN \\ University of Brawijaya, Faculty of Administrative Science, Department Business Administration, \\ Jalan MT. Haryono No 163, Malang, East Java, Indonesia, e-mail: u.nimran@ gmail.com
}

\begin{abstract}
Citation: Mastika, I.K., \& Nimran, U. (2020). DESTINATION BRANDING MODEL OF AN ECOLOGICAL TOURISM VILLAGE IN BALI, INDONESIA. GeoJournal of Tourism and Geosites, 31(3), 1068-1074. https://doi.org/10.30892/gtg.31319-542
\end{abstract}

\begin{abstract}
This paper is focuses on the branding process of ecological tourism village destinations in Bali Indonesia insightful their local indigenous systems. The research findings support and strengthen the concept of developing tourism village through the uniqueness and authenticity of local values, and interpret the reality of their ecotourism. Research uses constructivist paradigm with a qualitative approach. The conclusion shows that the branding destination of the ecological tourism village is constructed based on the Hindu cosmological system with the concept of "Tri Hita Karana" and the brand jargon is "Bali DWE the way to the real of Bali".
\end{abstract}

Key words: Branding, social construction, local indigenous, ecological tourism village

\section{INTRODUCTION}

The idea of the formation of an ecological tourism village, known as Bali DWE, is related to concerns about the impact of enormous tourism development in Bali. The study of Dipayana and Sunarta (2015), underline that the development of tourism in Bali tends to address local people only as spectators, not as actors of tourism. To promote tourism, local people shift from the owner to be victims, for example, the agricultural sector succumbs to demands for tourism development, irrigation channels are closed to build roads, and rice fields are sold to build hotels. In short, Bali is more pro to the expansion of mass tourism infrastructure development.

Towards the expansion of mass tourism infrastructure development, there is a different response from the four villages in Bali, which were previously marginalized by tourism. These four villages in Bali form a joint network called the Village Ecotourism Network (JED, Jaringan Ekoturisme Desa). JED is a form of tourism village development with an emphasis on the context of village. The establishment of the JED was initiated by the Wisnu Foundation (one of the oldest environmental NGOs in Bali) based in Denpasar, Bali. JED was inaugurated in 2002, covering four villages in Bali, namely: (1) Banjar Dukuh in Sibetan Village; (2) a group of people in the Desa Adat Tenganan Pegringsingan; (3) Banjar Kiadan in Pelaga Village; and (4) Nusa Ceningan.

Unlike the general ecotourism development strategy, JED provides excellent attention to the social system of the Balinese people. They ensure that community life is regulated in the traditional village setting called "Desa Pekraman". Pekraman Village, which is a traditional institution. The principle of ecotourism development is in harmony with the values of Balinese local wisdom (Ichsan, 2014). In response to the increasingly complex challenges of Bali's ecotourism, JED expands the village ecotourism movement by allying tourist villages named Ecological Tourism Village (DWE). Bali DWE further develops branding with a view of local wisdom that grows and develops in the sociocultural life of the Balinese people. Bali DWE prioritizes the community's role in mitigate tourism village's destination environment. This thought is in line with the results of the study of Wahyuningtyas et al (2019) the non-structural mitigation conducted by the community is the dimension of knowledge, values, decision-making mechanisms, and group solidarity. These leads to important and unique aspect of the relationship between tourism and sustainable development, which is interaction, awareness and dependency (Firdaus et al., 2019).

Thus, this paper explores and finds out the efforts of the Balinese tourism village movement in understanding, utilizing, int roducing, and preserving the values of local wisdom in the ecological tourist village movement in its region. This idea is in line with the idea that the development of village ecotourism must be oriented to nature and cultural conservation and involves the role of visitor togetherness as unique interest tourists (Tajeddini et al., 2017). The JED development strategy is based on the social system of the community life is regulated in an "adat" village setting called "Desa Pakraman". Likewise, the strategy for the formation of the Bali DWE association as a brand marketing strategy for ecological tourism village destinations.

A brand is not just a name and logo, but is an organizations promise. The brand principle is not only functional benefits, but emotional, self-expression, and social benefits (Aaker, 2015). Brand are very powerful and serve as the core of marketing communications, strategic options, and the forces that influence an organization. In the case that a brand influences organizational strength, the concept of "internal brand" as Aaker (2015) applies, that is, branding that is rich and strong, is also connected to organizational values and culture which are then conveyed to everyone through stories. In the context of internl brands, it is a process of building a social image through social construction of reality (SCoR) of branding. As Loo and Davies (2006) say that Chinese brands basically contain a set of beliefs and applications that can be used for life, business, health, etc. Yang (2010) concluded that a brand without cultural values would lose "marketing support".

Brand as a rationality that is stated in the form of a name, logo, or symbol is a form of semiotics that contains two important aspects, namely the existence of a signifier and signified (Sobur, 2006). A brand is not just a sign, but also an image that is completely constructed into the image of an organization (Bungin, 2015). Brand has a meaning as well as a sign tool that will be a reference that contains information and become discourse in the community. The discourse involved brand makers with other experts, brand makers with tourists, tourists with ordinary people, and tourists with other tourists.

\footnotetext{
${ }^{*}$ Corresponding author
} 
Eberly (1992) states that social constructivism is sourced from culture and makes individuals as actors. Furthermore Searle (1996) states that social reality sees together between individuals and social institutions. Individuals have an agent function in serving social reality which is actually also the reality of social institutions that live in the metaphors of individual minds. In the contex of phenomenology, Berger and Luckmann (1966) states that SCoR through three simultaneous processes, namely: externalization, legitimacy of objectivity, and internalization. Bungin (2015) included mass media as an important phenomenon in the process of SCoR as well as the direction and power of mass media in society. In its development the SCoR of Berger and Luckmann (1966) has gone through several processes of phenomenological thinking, critical thinking, and post-modern thinking to date (Yang, 2010; Bungin, 2015).

The views of the phenomenologists since the arguments of Berger and Luckmann (1966) say that the social process of society takes place naturally, gaining criticism from critical thinking and post-modernists. Eberle (1992) of critical thinking groups saw SCoR Berger and Luckmann considered too sluggish and functionalist and limited SCoR thought. Further the emergence of post-modern thought by 2000 criticized that SCoR Berger and Luckmann (1966) emphasized the dominant ideology underlying the content of a social construction message against reality should not exist. Truth is nominalism from idealism, intercultural communication affects scientific truths, the power of truth is the same as the sand building, therefore there is no scientific truth, that there is only social fact (Hacking, 2000; Bungin, 2001). Bungin (2015) incorporated the mass media as the most important phenomenon in the externalization process, the legitimacy of objectivity, and the internalization. A description of the SCoR above provides a rationale for reviewing the branding model of the ecological tourism village.

\section{LITERATURE REVIEW}

Village tourism is an ideal model to realize community-based tourism development and encourages the participation of local communities in managing village tourism destinations. Ecotourism development through ecological tourism villages can reduce the mass tourism industry's potential to degrade the quality of the environment. The tourism industry often exploits the potential of nature (agricultural land); thus, it has affected land conversion, and this trend is increasingly widespread (Dipayana and Sunarta, 2015). Tourism also involves the potential for the emergence of hedonic behavior, the shifting of traditional values of local cultures, and insufficient community involvement (Urbanus and Febianti, 2017). In rural communities, the socio-cultural life values are manifested, maintained, preserved as important customs and known as local wisdom or local indigenous traditions (Mastika et al., 2018). The values of local indigenous contain adaptive forms of mitigation for the community in managing their ecological area (Stone and Nyaupane, 2016). Ecotourism management model is unique because the villagers perform all the roles (Arida, 2016). The results of the Astawa et al (2019) study, found that the components of harmonious culture related to the belief in the greatness of God through prayer or prayer activities before an activity. In doing activities always pray based on their own beliefs and it had been conducted routinely before the beginning and end of activities. Each participant in an event was directly involved in the ceremonial or cultural activities in the village to maintain a balance of nature through ceremonial drafting set. Reminding village communities that they have local indigenous and values is essential (Aulia and Arya, 2010). They also compiled the local history of the village, adaptive mitigation (Stone and Nyaupane, 2016), and zoning of spatial use. Tourists who consume ecotourism products will gain an understanding of the methods of environmental conservation (natural and cultural) through experience and interaction with local communities (Fill, 2013).

Brand is an immeasurable concept (Kotler and Pfoertsch, 2006), but visually, the brand can be a logo, tagline, or symbol (Lusi, 2008). The symbolic dimensions of brand practices put them in cultural settings as cultural phenomena. Brands are symbolic articulators of production and consumption (O'Reilly, 2010). Signs are a form of communicative information that stands for something else that can be understood. Brand has a critical role in creating the experience promised by the brand (Bungin, 2015; Morgan and Pritchard, 2004). Therefore, the brand as a message product has contacts with various aspects of communication (Bungin, 2015; Carah, 2013; Rossiter and Bellman, 2005).

The brands are inherent in heritage sites, and the consequences for the complexity of how values are negotiated through knowledge sharing outside the market (Mortensen, 2014). Knowledge development involves providing knowledge, passing on experiences, instilling values and local indigenous, and constant training for collaboration (Sangthong and Rinthaisong, 2015). For the development of tourist activities, one of key elements is designing tourism for the community that adheres to the concepts of sustainable tourism, benefit the community and its environment (Desbiolles, 2010; Sangchumnong, 2018). Interpretation was identified as a tool for receiving feedback from tourists (Muneenam et al., 2017). The branding of reality is a process of the social construction, that includes the externalization stage, the legitimacy of objectivity, and internalization. In the externalization stage, interested parties convey ideas and information aimed at certain groups in the community, starting with individuals, families, and communities (Hacking, 2000). In the process of legitimacy objectivity is a ratification of the logical explanations of the process of institutionalizing socio-cultural values into society. This social process provides rational reasons for the destination brand that has been conveyed to the community in the institutionalization process (Bungin, 2015). In the internalization is a bedrock to understand the meaning of the following: "My Fellow" (i.e., the understanding of individuals and others) and the world as a social reality full of meaning. Through the realization that the creation of meaning is not autonomous becouse of the marginalization of individuals, it begins with individuals who "take over" the world that other people already have. In the process of taking over, individuals can modify the world and can reconstruct the world creatively (Bungin, 2015).

Meanwhile critical thinkers and post-modern views emphasize the phenomenon process and the social construction process against reality (Hacking, 2000; Bungin, 2001). The influence of communication emphasizes the total change of social construction phenomenon to modern reality by incorporating the mass media as the most important phenomenon in the externalization process, legitimacy of objectivity, and internalization (Bungin, 2015). A theoretical view of social construction of reality is also followed by the development of changing tourism. The realization of tourism development in various countries, as well as awareness of the importance of preserving tourism assets, changes in tourism lead to a form of sustainable tourism development (ecotourism) based on the ecological, economic and social culture aspects of the local community (Malik et al., 2019). In response to the dynamics of tourism development, the Indonesian government has compiled the Strategic Plan of the Indonesian Ministry of Tourism 2018-2019. In the aspect of Potential Tourism Destination Development states that "Rural-based tourism development (tourism villages) will drive tourism economic activities in rural areas which will prevent urbanization and encourage conservation of nature which in turn will reduce global warming". Tourism destinations are developed based on potential tourist attractions and community empowerment in a completed and sustainable system (Yahya, 2018).

\section{METHODS}

This study uses the constructivist paradigm. The social reality observed by someone cannot be generalized to everyone, as positivist usually do. A social reality is relative, based on the perspective of interpretativism which is divided into three types, namely symbolic, phenomenological, and hermeneutic interactions (Eriyanto, 2004; Bungin, 2008). Using a qualitative approach aimed at understanding and meaning various phenomena that exist and is a research procedure that produces descriptive data in the form of written or oral words from 
people and observable behavior (Moleong, 2000). Characteristics of qualitative research are: 1) natural; 2) data are descriptive not numbers; 3) inductive data analysis; and 4) meaning is very important in qualitative research (Bogdan and Biklen, 1982; Denzin and Lincoln, 2009). Data collection tools use direct observation, in-depth interviews, and documentation studies (Marshall and Rossman, 1989). Data analysis is performed from the time data collection continues until the research is complete and the data obtained is considered credible (Miles and Huberman, 1984). Data were obtained from informants selected purposively, i.e. initiators of ecological tourism villages (Director of Bali Wisnu Foundation) and Director of the Village Ecotourism Network. From both initiators we obtained information about the background of the formation of village ecotourism network (VEN) and association of ecological tourism village (BALI DWE) related to the philosophy, principles and practice of local indigenous ecological tourism village. The leaders and subjects of ecotourism in the village, as the spearhead who have field experience interacting with visitors, have a responsibility to implement the values of local indigenous in practice through positive story telling and linkage attitudes that are able to satisfy visitors. Interviews with foreign visitors who were met incidentally were done to get responses to the implementation of the ecological tourism village that they experienced during their visit.

\section{RESULTS AND DISCUSSION}

\section{BALI DWE branding with local indigenous view}

In constructing ecological tourism villages, the main aspects to be considered are the value of local indigenousness related to aspects of the Hindu cosmology system in Bali namely, "Tri Hita Karana" (Windia et al., 2011). The importance of the Bali cosmology system stated by the Director of Wisnu Foundation (in 2016):

"... we truly believe that the Balinese cosmology system is so related to the conception of believe and how we treat ourselves and the environment. Some of the awig-awig of our village are written and some are not, but after we invite them to see, interpret, understand what they have, they become aware to manifest it in daily life, individually, socially, including in the ecological tourism village practice. "

In the context of Tri Hita Karana, the area of a Pakraman village is divided into three zones: (1) the sanctity zone called "Parahyangan", (2) the limited-use zone called "Palemahan", and (3) the utilization zone called "Pawongan". The sanctity zone is for the establishment of temples and the protection of flora and fauna as a conservation area for wealth in a Pakraman village (Surpa, 2004). The following is the diagram of the Bali DWE construction model with Balinese cosmological systems (Figure 1).

\section{CONSTRUGTION OF EGOLOGICAL TOURISM VILLAGE} OF INSIGHTFUL BALINESE COSMOLOGY

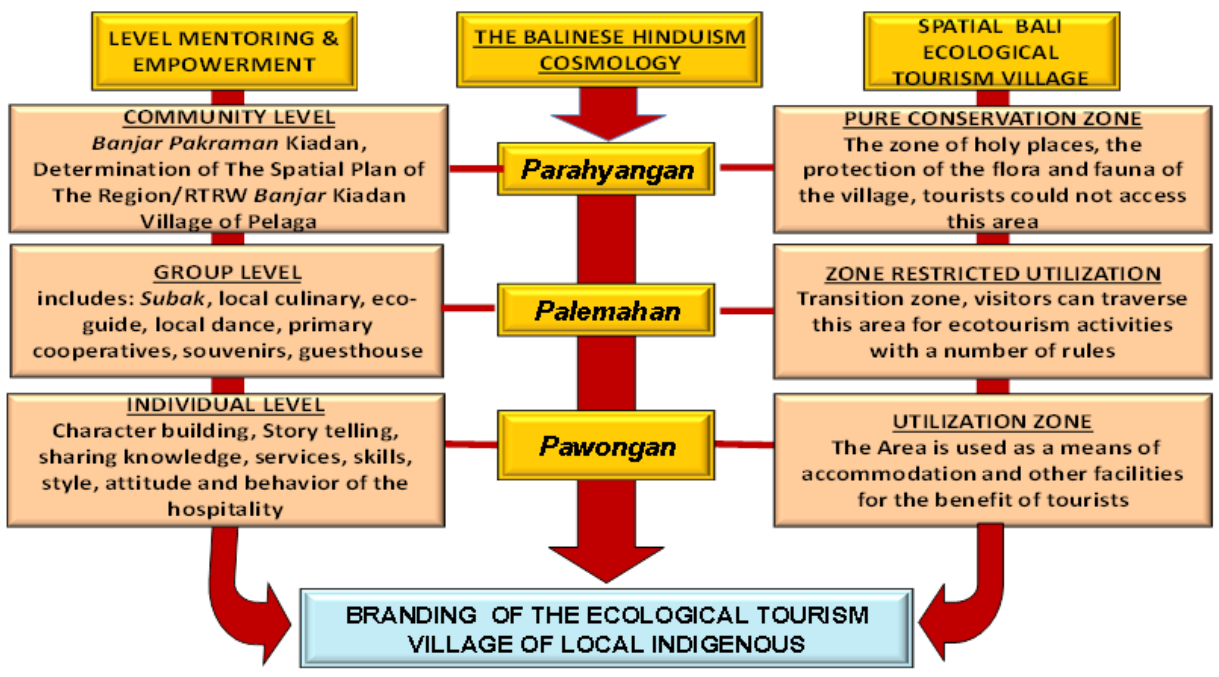

Figure 1. Social construction of reality model of BALI DWE

The limited-use zone is a transition zone, where tourists can cross for ecotourism activities if they follow a number of rules.

The initiators of village ecotourism (Wisnu Foundation and VEN) in providing assistance and empowerment to village communities can also be grouped into three levels: (1) community (2) group; and (3) individual. At the community level, the activists of an ecotourism village diligently and patiently build awareness and understanding of the community regarding the importance of their role in developing village ecotourism. The Director of Wisnu Foundation (in 2016) stated:

"... for us decision making is the most important issue, that every issue is discussed in community meeting forums. The four villages of VEN members have made mapping of the village area. Developing a regional spatial plan (RSP) is the most important activity at the beginning of ecotourism planning. Through regional mapping and space management plans, regional zones are then established, including the utilization zone for ecotourism".

The group level addresses the concerns that mere individuals cannot. These duties of this functional group include providing services for visitors' needs, such as objects of coffee plantation-based ecotourism, rural homestays, culinary offerings, souvenirs, and local guides. The Director of VEN (in 2016) stated:

"... with the richness of cultural arts and natural beauty, they design living quarters, types of art, attractions that are unique, interesting and agreed upon, both in determining prices and contributing to the owners, the subjects, and their respective villages. To create the comfort of village ecotourism, we build a coffee park, coffee gardens as a garden of life, we make their villages a tourist destination, economically creating employment opportunities such as local guides, culinary, village barista, art performances, and homestays".

The last level is the individual level. The individual level interacts with the pawongan level as a zone of utilization of an ecotourism village. The individual level prioritizes individual skills in interacting with visitors. The Wisnu Foundation and VEN provide education and capacity building training to build pride in their local indigenous values. They also introduced the socio-cultural assets to the visitors by promoting hospitality. The Director of Wisnu Foundation (in 2016) stated:

"... The values become the selling point, the products in the form of storytelling must be contextualized that we honestly say, we honestly 
tell, that there is an effort that we do in creating a quality product. We say the interaction and meeting are knowledge sharing, not like host and guest but visitors feel that there is a linking attitude. They ask we answer and vice versa. In certain contexts, capacity building creates a number of division of tasks needed, for example being a local guide, order, culinarian, barista, guest house and others".

\section{BALI DWE Social Construction}

The spatial arrangement of the village then required harmonization and ratification by the district government. The process of the social construction of the branding reality of Bali's Ecological Tourism Village destinations includes the externalization stage, the legitimacy of objectivity, and internalization.

\section{Externalization}

In the context of social construction toward the reality of branding village ecotourism in Bali, it cannot be separated from the values of Bali's local indigenous people. The values of local indigenous people and the concept of the Balinese cosmology system are manifestations of the sacred teachings of Hinduism. These values are a way of life in the socio-cultural life of the Balinese people. With a touch of local aesthetic values and local architecture, the Balinese lifestyle has a character of uniqueness, authenticity, and originality. Related to the importance of the idea to pay attention to and carry out the values of local indigenous people in the development of ecological tourism villages, the Director of Wisnu Foundation (in 2016) stated:

"... Technologically maybe people in silicon B are more powerful, but in creativity, rituality, maybe we have a better position. It is in its socio-cultural context, from the context of uniqueness, from the island's artifacts also vary, from its history, in terms of geography and belief system, where the forest must be maintained, how the symbolization of "Goddess" must be maintained, it is extraordinary.

People who have realized the treasure of local indigenousness have made it a social investment in the development of village ecotourism. The values of local indigenousness and practices in the form of the culture and social life of the community are the products and attractions of village ecotourism that are of high quality because they are unique and authentic.

\section{Legitimacy of Objectivity}

At the stage of the objectivity of legitimacy, the initiators in mentoring and training strive to demonstrate the benefits of village tourism in a social, environmental, and economic manner for the community. In the Pakraman village administration structure, ethics as a way of life in society is regulated through awig-awig (the law that applies in a Pakraman village), both inward relations and outside relations, including the village ecotourism context. In the context of the importance of local community-based management, the Director of the Wisnu Foundation (in 2016) stated:

"... in the context of implementing their customs, professional values are still difficult to be relied on. However, there are very many new capacities and skills that must also be added or supplemented according to their needs towards professional management through capacity building training and community organizing."

The objectivity of legitimacy is also directed to make the village community aware of the importance of mutual respect between local residents and visitors. The efforts made by the initiator introduce the community to foreign guests and the interactions that occurred.

\section{Internalization}

The social construction process of the social branding reality of the " BALI DWE" destination now enters the next stage the "internalization" process. The internalization process strengthens the social system by accepting social construction towards the reality of destination branding. The process of internalization in the context of the supply side (internal branding) is closely related to the system of government in a Pekraman village in Bali. In a Pakraman village administration structure, ethics as a way of life for the community is regulated through awig-awig (the law that applies in Pakraman village), both inward relations and outside relations, including in the village ecotourism context. The Director of Wisnu Foundation (in 2016) stated:

"... We invited them (training participants in capacity building) to walk around, then the questions came to the calculation that if this was the tourism model we had, what would we achieve? We invited them to try to calculate the water use, land use, transportation, profit sharing, environmental impact, and cultural impact. Finally, they began to understand. These are the processes of awareness to make them understand the constellation of who gets what task.

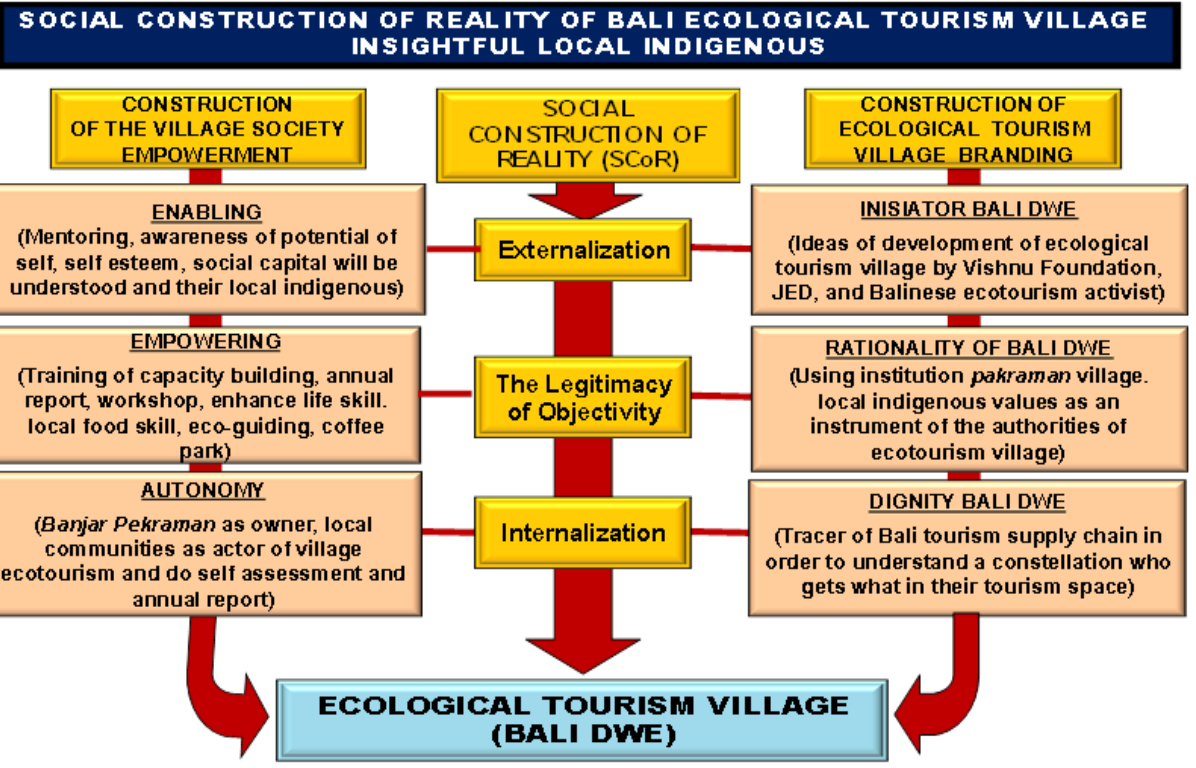

Figure 2. Social construction of reality model of BALI DWE 


\section{BALI DWE Branding Model with Local Indigenous Views.}

The village ecotourism brand in the VEN environment that later morphed into the concept of an "Ecological Tourism Village" (DWE) is an effort by the Wisnu Foundation, VEN, and Bali ecotourism activists to reconstruct the Bali ecological tourism village brand in the form of the "BALI DWE" logo, with the "Temple" symbol on letter A of the word "BALI". The tagline contained in the BALI DWE brand is "The Way to Real Bali". The social image displayed in the visualization of the background is a typical Balinese house and a Balinese figure that wears a Balinese headband (udeng/destar). Thus, the BALI DWE brand portrays the uniqueness, authenticity, and distinctiveness of Bali's Ecological Tourism Village. Branding is an effort to construct the brand. Therefore, the branding construction of a local indigenous ecological tourism village, the theme of this study, represents, the efforts of local communities in the research location (Banjar Kiadan) accompanied by the Wisnu Foundation, VEN, and concerned Bali eco-tourists/the initiators in constructing BALI DWE Brand. Based on the constructivism perspective, the study aimed to explore the efforts of the initiators to create a destination brand (BALI DWE). The following is the diagram of the brand construction of Bali DWE (Figure 3).

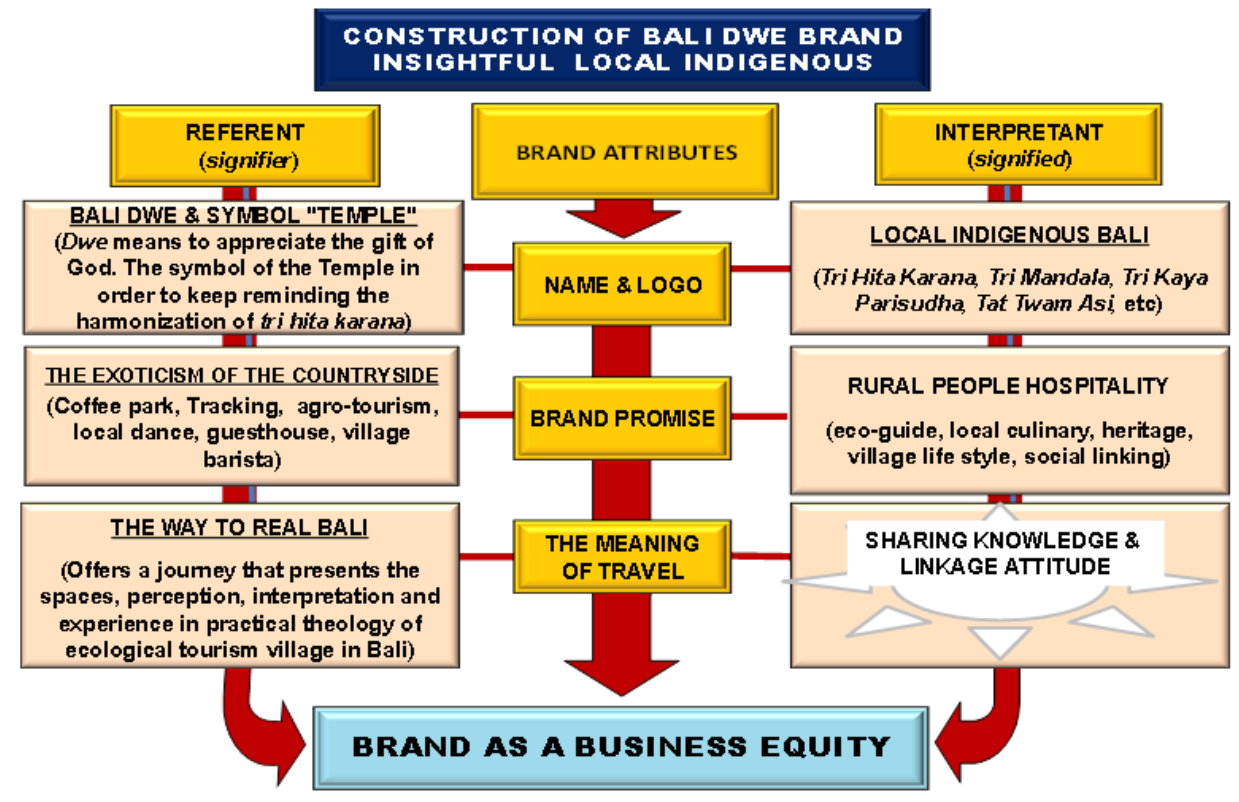

Figure 3. Construction of BALI DWE brand

In developing ecotourism products, the tangible and intangible products of the foundation have various obstacles and challenges to overcome. The encouraging results have been observed since the expansion and metamorphosis of VEN to the BALI DWE (Ecological Tourism Village) project. BALI DWE project expanded the coverage of villages involved in developing village ecotourism networks. A successful brand requires marketing communication support and social construction to ensure that the brand in question becomes solid. Complex relationships between brand and marketing communication can be described through the view of communication, that is, the brand itself is a message product that has complicated content. However, apart from the complexity of the brand, it remains a message in the marketing communication process. Brand as a form of marketing communication requires that the communication process is a transmission process that interprets symbols among individuals. In the practice of ecotourism, brand communication is performed through storytelling, knowledge sharing, and attitude linkages between hosts and guests.

Brands assemble social spaces that use the communicative capacity of cultural actors. A mode of branding that works by managing open social processes depends on affective personnel. Affective personnel involves the ability of individuals to produce certain meanings and feelings and opens social capacity. Branding operates as the main mode through which tourism value is considered to be circulating and reproducing, becoming available to exclusive regimes and capturing new economic benefits. As a high mechanism for mobilizing symbolic differences, brands now also appear to regulate values outside the domain of economic exchange. Brand practices and logic increasingly dominate tourism organizations both explicitly and implicitly.

BALI DWE as a brand in the form of logo, symbol, and tagline visualize the uniqueness, authenticity, and exoticism of Bali that has been released and published to the public. The BALI DWE brand is published as a form of marketing communication to provide an understanding of the destination product image and to attract visitors and interpretation was identified as a tool for receiving feedback from tourists. Based on the publication of the brand, the concept and context of the BALI DWE brand can then be analyzed.

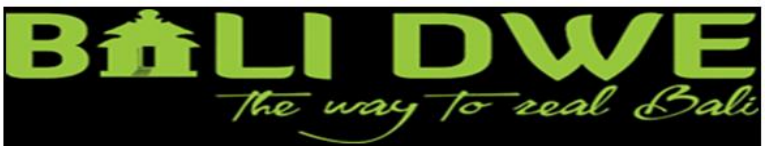

Figure 4. BALI DWE brand (Source: Mastika, 2018)

In the context of the destination brand and internal brand of BALI DWE as Logo, Symbol, and Tagline, it is constructed based on local indigenous values of Bali, which can be explained based on the context of brand theory and semiotic theory. Based on brand theory, it can be identified on three brand attributes:

1) Name and Logo, aspects of signifier or referent (semiotic theory), in the form of the logo "BALI DWE" and the "Temple" symbol in the letter A of the word BALI. "Dwe" means respecting God's gift. The symbol of the temple, reminds Balinese to maintain the harmonization of Tri Hita Karana, the signified or interpretent aspects (semiotic theory), i.e. the local indigenous concepts of Bali.

2) Promise of Brand, signifier or referent aspects, in the form of rural exoticism, include coffee park, tracking, agro tourism, heritage, 
rural house style, lifestyle of the village community, and so on. Signified or interpretent aspects in the form of rural people hospitality, include local eco-guide, local culinary, guesthouse, village barista, souvenirs, local dance, and social linkage.

3) Value of Traveling, the signifier or referent aspects, in the form of the tagline "The Way to Real Bali" mean offering a trip that presents spaces for interpretation, perception, and experience for travelers in the ecological tourism villages in Bali. The signified or interpretent aspects are the sharing of knowledge and linking attitude between hosts and guests of the ecological tourism villages.

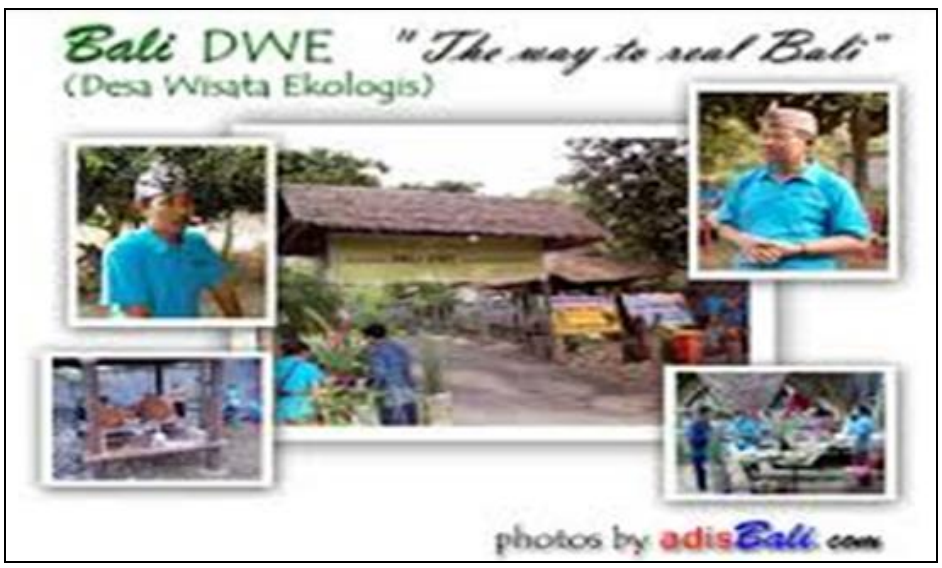

Figure 5. BALI DWE branding (Source: Mastika, 2018)

\section{CONCLUSION}

The implementation of the BALI DWE brand was constructed based on the Bali cosmological system, known as the Tri Hita Karana concept, and comprises (1) Parahyangan, (2) Palemahan, and (3) Pawongan. By contrast, in the context of the branding construction of ecological tourism villages as part of BALI DWE, the three stages of the simultaneous process are (1) externalization, (2) the objectivity of legitimacy, and (3) internalization.

At each stage of the social construction BALI DWE's branding reality included Bali local wisdoms; thus, the brand construction of "BALI DWE" is a form of internal branding development, evidenced, by the following: (1) the brand's visions and missions are supported by culture and the application of brand values; (2) leadership is used a brand driver, and in this case, the role of the Wisnu Foundation, VEN as a catalyst, and the Pekraman village model to compare the attitudes and behavior of the community and the managers of the ecotourism village according to their local indigenousness values; (4) the "fun" element in the brand in the form of a promise from the tagline "The way to real Bali" is an experience that will please visitors and help them find meanings associated with the brand; and (5) BALI DWE promote inclusivity and carries out new initiatives that are gradually increasing in number.

Several dimensions influence the success of BALI DWE's internal branding: (1) the typical character of the island of Bali as "The Island of Paradise" by the world community; (2) the hospitality of Balinese people, which is a business value and a specific practice to convey value to tourists; (3) the concept of knowledge sharing and linkage attitude developed in the practice of village ecotourism having good educational and expertise values to convey and revive village ecotourism brands; and (4) conducting an assessment of a series of internal branding process activities and assessing the influence of the process conducted.

\section{LIMITATION AND RECOMENDATIONS}

This research is focused on the branding characteristics of Bali DWE in Ecotourism network in the JED environment in Bali in implementing local indigenous values in the practice of organizing the village ecotourism. This study focuses more on laying the basis for the establishment of an ecological tourism village zoning system based on the concept of Hindu cosmology in Bali. To understanding the effectiveness of investment applications of local cultural values into the standards of ecotourism adequacy criteria which include five important aspects, namely: 1) natural resource conservation objectives; 2) involvement of local communities; 3) development of local economies; 4) development of tourism products; 5) minimal environmental impacts, requiring measurable studies. This research has not answered all these aspects of measurable. Therefore, more research is needed to answer the fulfillment of the criteria of ecotourism sufficiency from various aspects of its contribution, so that the purpose of ecotourism development as an alternative form of sustainable tourism development can be maintained.

\section{Acknowledgment}

I would like to thank the editor and anonymous reviewers for their suggestions, Director of Wisnu Foundation, Manager and staff members of JED or the Bali Village Ecotourism Network in Denpasar, Bali - Indonesia for their help and hospitality during my stays and research there.

\section{REFERENCES}

Aaker, D. (2015). Aaker on Branding, 20 Prinsip Esensial Mengelola dan Mengembangkan Brand (20 Essential Principles of Managing and Developing a Brand). Gramedia Pustaka Utama, Jakarta, Indonesia.

Arida, I.N. (2016). Dinamika Ekowisata Tri Ning Tri di Bali (The Dynamics of Tri Ning Tri Ecotourism in Bali). Pustaka Larasan bekerjasama dengan Fakultas Pariwisata Universitas Udayana, Denpasar, Indonesia.

Astawa, I.P., Sukawati, T.G.R., \& Sugiartha, I.N.G. (2019). Developing a Harmonious Culture-Based Sustainable Event Model in Bali Tourism Village. GeoJournal of Tourism and Geosites, 25(2), 446-462. https://doi.org/10.30892/gtg.25214-372

Aulia, T.O.S., \& Arya, H.D. (2010). Kearifan Lokal Dalam Pengelolaan Sumberdaya Air Di Kampung Kuta (Local Wisdom in Water Resources Management in Kuta Village). Jurnal Transdisiplin Sosiologi, Komunikasi, dan Ekologi Manusia, 04(03), 345-355 (in Indonesian).

Berger, P.L., \& Luckmann, T. (1966). The Social Construction of Reality, A treatise in the Sociology of Knowledge. Anchor Books, New York, USA.

Bogdan, R.C., \& Biklen, S.K. (1982). Qualitative Reseach for Eduication. Allyn \& Bacon, Inc., London, England.

Bungin, B. (2001). Imaji Media Massa: Konstruksi dari Makna Realitas Iklan Televisi dalam Masyarakat Kapitalistik (Image Mass Media: Construction of the Reality Meaning of Television Commercials in the Capitalistic Society). Doctoral Dissertation, Universitas Airlangga, Surabaya, Indonesia. 
Bungin, B. (2008). Konstruksi Realitas Sosial Media, Iklan Televisi dan Keputusan Konsumen serta Kritik Terhadap Peter L. Berger dan Thomas Luckmann (Construction of the reality of social Media, television commercials and consumer decisions and criticism of Peter L. Berger and Thomas Luckmann). Pranda Media, Jakarta, Indonesia.

Bungin, B. (2015). Komunikasi Pariwisata (Tourism Communication), Pemasaran dan Brand (Marketing and Brand). Prenadamedia Group, Jakarta, Indonesia.

Carah, N. (2013). Brand Value: How Affective Labour Helps Create Brands. Consumption Markets \& Culture, 17(4), 346-366. https://doi.org/10.1080/10253866.2013.847435

Denzin, N.K., \& Lincoln, Y.S. (2009). Hand Book of Qualitative Research. Penerbit Pustaka Pelajar, Yogyakarta, Indonesia.

Desbiolles, F.H. (2010). Indigenous Ecotourism's Role In Transforming Ecological Consciousness. Journal of Ecotourism, 8(2), $144-160$.

Dipayana, A. \& Sunarta, I.N. (2015). Dampak Pariwisata Terhadap Alih Fungsi Lahan di Desa Tibubeneng Kecamatan Kuta Utara Kabupaten Badung Kabupaten Badung (The Impact of Tourism on Land Transfer in the Village of Tibubeneng, North Kuta District, Badung). Jurnal Destinasi Pariwisata, 3(2), 58-66 (in Indonesian).

Eberly, T.S. (1992). A paradigm for the sosiology of knowledge: "The social construction of reality" after 25 years. Journal Schweizerisch Zeitschrift fur soziologie: Revue Suisse de Sociologie, 18(-), 493-502.

Eriyanto. (2004). Analisis Framing (Analysis Farming). LkiS, Yogyakarta, Indonesia.

Fill, C. (2013). Marketing Communication, Brand, Experiences and Participation. Sixth Edition, Pearson, Harlow, UK.

Firdaus, F., Shalihin, S., Anggreta, D.K., Yasin, F., \& Tutri, R. (2019). Improving the Benefits of Keramba into Tourism Activities: An Effort to Reduce the Ecological Impact of Aquaculture in Maninjau Lake, Indonesia. GeoJournal of Tourism and Geosites, 26(3), 726-736. https://doi.org/ 10.30892/gtg.26304-392

Hacking, I. (2000). The Social Construction of What. Harvard College, USA.

Ichsan, A.K.N. (2014). Kearifan Lokal Bali Dalam Mereduksi Sisi Gelap Pembangunan Sektor Pariwisata (Bali's Local Wisdom in Reducing the Dark Side of the Development of the Tourism Sector). Fakultas Ekonomi Dan Bisnis Universitas Airlangga, Surabaya, Indonesia.

Kotler, P., \& Pfoertsch, W. (2006). B2B Brand Management. BIP, Jakarta, Indonesia.

Loo, T., \& Davies, G. (2006). Branding China. The Ultimate Challenge in Reputation Management. Corporate Reputation Review, 9(3), 198-210.

Lusi, E.P. (2008). Representasi Identitas Kota Surabaya: Analisis Wacana (Representation of Surabaya City Identity: Discourse Analysis City Branding "Sparkling Surabaya". Universitas Airlangga, Surabaya, Indonesia.

Malik, A., Rahim, A., \& Sideng, U. (2019). Pariwisata \& Pengembangan Ekowisata Mangrove (Mangrove Ecotourism Tourism \& Development). Diterbitkan oleh Badan Penerbit Universitas Negeri Makasar, Makasar, Indonesia.

Marshall, C., \& Rossman, G.B. (1989). Designing Qualitative Research. Sage Publication, Inc., London, UK.

Mastika, I.K. (2018). Konstruksi Branding Ekowisata Desa Berwawasan Kearifan Lokal (Kajian di Banjar Kiadan, Desa Pelaga, Kecamatan Petang, Kabupaten Badung, Provinsi Bali) (Branding Construction of Ecotourism Village with Local Wisdom Insights (Study in Banjar Kiadan, Pelaga Village, Petang Sub District, Badung Regency, Bali Province). Doctoral Dissertation, Program Doktor Ilmu Administrasi, Fakultas Ilmu Sosial dan Ilmu Politik, Universitas Jember, Indonesia.

Mastika, I.K., Yuswadi, H., Budihardjo, A., \& Poernomo, D. (2018). Local Indigenous Branding: Bali Ecological Tourism Village. International Journal Of Scientific And Research Publication. 8(1), 211-218.

Miles, M.B., \& Huberman, A.M. (1984). Data Management and Analysis Methodes. Handbook of Qualitative Research. Editors: Norman K. Denzin and Yvonna S. Lincoln, Sage Publication. Inc., London, England.

Moleong, L.J. (2000). Metodologi Penelitian Kualitatif (Qualitative Research Methodology). Remaja Rosdakarya, Bandung, Indonesia.

Morgan, N., \& Pritchard, A. (2004). Destination Brands: Managing Place Reputation, R. Pride (Eds). Elsevier Butterworth-Heinemann, Burlington, Kanada.

Mortensen, L. (2014). Branding Copan: Valuing Cultural Distinction in an Archaeological Tourism Destination. Journal of Tourism and Cultural Change, 12(3), 237-252. https://doi.org/10.1080/14766825.2014.939392.

Muneenam, U., Suwannattachote, P., \& Mustikasari, R.S. (2017). Interpretation Of Shared Culture of Baba ad Nyonya For Tourism Linkage Of Four Countries In The ASEAN Community. Kasetsart Journal Of Social Sciences 38(-), 251-258.

O’Reilly, D. (2010). Cultural Brands/Branding Cultures. Journal of Marketing Management, 21(5-6), 573-588. https://doi.org/ 10.1362/0267257054307336

Rossiter, J.R., \& Bellman. (2005). Marketing Communication, Theory and Application. Pearson Prentice Hall, Frenchs Forest, NSW, Australia.

Sangthong, K., \& Rinthaisong, I. (2015). Collaboration between Hulong Subdistrict Administrative Organization and Hulong Community on Flood Management in Pak Phanang District, Nakhon Si Thammarat Province, Songkla-Thailand. Kasetsart Journal of Social Sciences. (Soc. Sci) 36(-), 165-172. https://so04.tci-thaijo.org/index.php/kjss/article/view/243118.

Searle, J.R. (1996). The Construction of Social Reality. Penguin Books, London, England.

Sobur, A. (2006). Semiotika Komunikasi (Semiotics Communication). PT. Remaja Rosdakarya, Bandung, Indonesia.

Stone, M.T., \& Nyaupane, G.P. (2016). Ecotourism Influence On Community Needs And The Functions Of Protected Areas: A Systems Thinking Approach. Journal Of Ecotourism, 16(3), 222-246. https://doi.org/ 10.1080/14724049.2016.1221959

Surpa, I.W. (2004). Eksistensi Desa Adat dan Desa Dinas Di Bali (The Existence of Traditional Village and Official Village in Bali). Pustaka Bali Post, Denpasar, Bali, Indonesia.

Tajeddini, K., Walle, A.H., \& Denisa, M. (2017). Enterprising Women, Tourism, and Development: The Case of Bali. International Journal of Hospitality \& Tourism Administration, 18(2), 195-218. https://doi.org/10.1080/15256480.2016.1264906

Urbanus, I.N., \& Febianti. (2017). Analisis Dampak Perkembangan Pariwisata Terhadap Perilaku Konsumtif Masyarakat Wilayah Bali Selatan (The impact of tourism development impacts on community consumptive behavior of South Bali region). Jurnal Kepariwisataan dan Hospitalitas, 1(2), 118-133 (in Indonesian).

Windia, W., Dewi, \& Ratna K. (2011). Tri Hita Karana (Tri Hita Karana). Udayana University Press, Denpasar, Bali, Indonesia.

Wahyuningtyas N., Tanjung A., Idris I. \& Dewi K. (2019). Disaster Mitigation on Cultural Tourism in Lombok, Indonesia. GeoJournal of Tourism and Geosites, 27(4), 1227-1235. https://doi.org/10.30892/gtg.27409-428

Yahya, A. (2018). Rencana Strategis Kementerian Pariwisata 2018-2019 (Tourism Ministry's strategic Plan 2018-2019). Kementerian Pariwisata Republik Indonesia, Jakarta, Indonesia.

Yang, Y. (2010). The construction of brand culture based on corporate culture. International Journal of Business and Management, 5(4), 223-226. https://doi.org/10.5539/ijbm.v5n4p223 